\title{
Reason
}

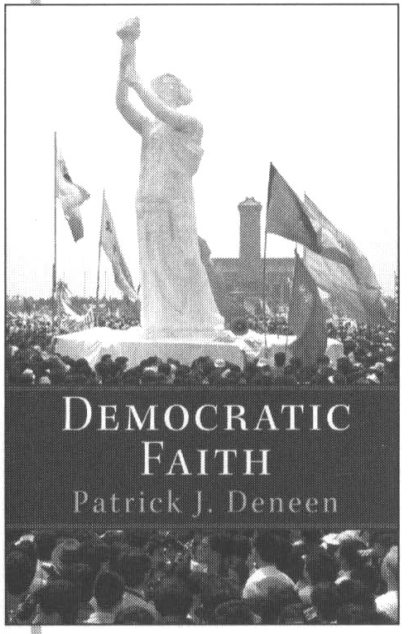

\section{Democratic Faith}

\section{Patrick Deneen}

Patrick Deneen proposes a form of "democratic realism" that recognizes democracy not as a regime with aspirations to perfection, but that justifies democracy as the regime most appropriate for imperfect humans.

"This is a powerful and poignant work in that it refines and deepens contemporary democratic theory.... Its relevance for our time resounds loudly." - Cornel West, author of Democracy Matters

New Forum Books

Cloth $\$ 45.00 \quad 0-691-11871-X$ Due September

\section{The JeWISH SOCIAL CONTRACT}

An Essay in Political Theology

\section{David Novak}

How can a traditional Jew participate politically and socially and in good faith in a modern democratic society? David Novak proposes that members of faithbased communities adhere to their own religious traditions when engaging in the political framework's public forums.

New Forum Books

Cloth $\$ 39.50$ 0-691-12210-5 Due November

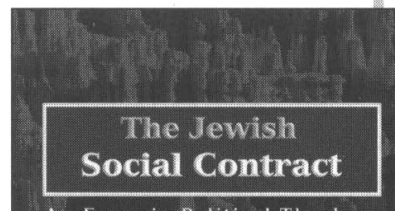

An Essay in Political Theology

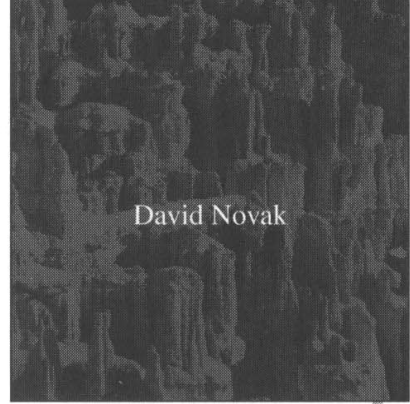

Celebrating 100 Years of Excellence

PRINCETON $800-777-4726$

University $\mathcal{P}$ ress $\begin{aligned} & \text { Read excerpts online } \\ & \text { www.pup.princeton.edu }\end{aligned}$ 
Forthcoming in the Fall Issue

A Bicentenary Celebration of Tocqueville's Birth including articles by

Aurleian Craiutu on Tocqueville's Paradoxical Moderation Aristide Tessitore on Tocqueville and Gobineau

Dana Villa on Hegel, Tocqueville, and "Individualism" Roger Boesche on the Dark Side of Tocquville Robert Gannet on Tocqueville and Local Government

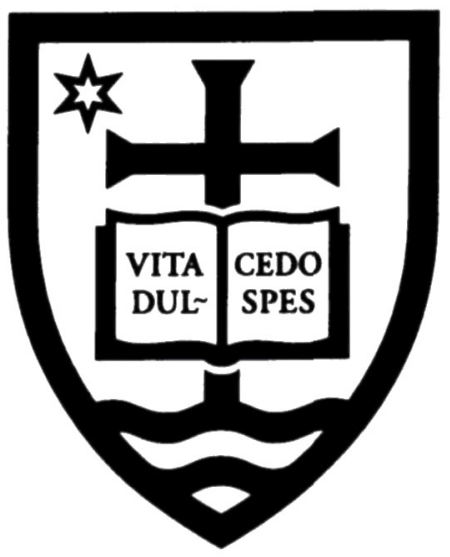

